\title{
Congenital Bilateral Perisylvian Syndrome: A Case Report
}

\section{Konjenital Bilateral Perisilviyan Sendrom: Olgu Sunumu}

\author{
Sibel GAZIOĞLU, ${ }^{1}$ Vildan ALTUNAYOĞLU ÇAKMAK, ${ }^{1}$ ilker EYÜBOĞLU, ${ }^{2}$ \\ Ramazan AKPINAR, ${ }^{1}$ Sibel VELIOĞLU'
}

'Department of Neurology, Karadeniz Technical University Faculty of Medicine, Trabzon;

2Department of Radiology, Karadeniz Technical University Faculty of Medicine, Trabzon

\begin{abstract}
Summary
Congenital bilateral perisylvian syndrome (CBPS) is a congenital neuronal migration disorder characterized by epilepsy, pseudobulbar palsy, cognitive deficits and bilateral perisylvian abnormalities at brain imaging. We report a case of a 44-year-old male admitted with refractory seizures and drop attacks and diagnosed with CBPS after detailed history, neurological examination and magnetic resonance imaging (MRI) findings. The patient had been suffering from seizures since the age of 13 . He had generalized tonic-clonic seizures once a month and tonic/ atonic drop attacks repeating daily in spite of antiepileptic drug therapy. Neurological examination showed pyramidal signs, predominantly on the right side, pseudobulbar paresis and mild cognitive impairment. Interictal electroencephalogram (EEG) revealed bilateral frontotemporal sharp-slow wave discharges. MRI revealed bilateral perisylvian local cortical thickening and polymicrogyria. Patients with refractory seizures should undergo detailed investigation, including brain imaging for the possibility of having a specific syndrome. Intractable seizures, pseudobulbar signs and mental retardation suggest the diagnosis of CBPS. Brain MRI plays an important role in the diagnosis of this syndrome.
\end{abstract}

Key words: Congenital bilateral perisylvian syndrome; drop attack; epilepsy; polymicrogyria.

\section{Özet}

Konjenital bilateral perisilviyan sendrom (KBPS) epilepsi, psödobulber paralizi, kognitif hasar ve beyin görüntülemesinde iki taraflı perisilviyan anormalliklerle karakterize bir nöronal migrasyon bozukluğudur. Bu yazıda tedaviye dirençli nöbetler ve düşme atakları ile başvuran ve detaylı öykü, nörolojik muayene ve manyetik rezonans görüntüleme (MRG) bulguları ile KBPS tanısı almış 44 yaşında bir erkek olgu sunuldu. On üç yaşından beri nöbet şikayeti olan hastanın antiepileptik tedaviye rağmen ayda bir olan jeneralize tonik klonik nöbetleri ve her gün olan tonik/atonik düşme atakları mevcuttu. Nörolojik muayenesinde sağ tarafta daha belirgin olan piramidal bulgular, psödobulber paralizi ve hafif kognitif bozulma mevcuttu. İnteriktal elektroensefalografisinde iki taraflı frontotemporal keskin yavaş dalga deşarları mevcuttu. MRG'sinde iki taraflı perisilviyan local kortikal kalınlaşma ve polimikrogri mevcuttu. Tedaviye dirençli nöbetleri olan hastalar mutlaka spesifik bir sendrom olasılığı açısından beyin görüntülemesini de içeren detaylı bir inceleme yapılarak değerlendirilmelidir. Tedaviye dirençli nöbetler, psödobulber bulgular ve mental retardasyon KBPS tanısını destekler. Beyin MRG incelemesi bu sendromun tanısında önemli role sahiptir.

Anahtar sözcükler: Doğuştan iki taraflı perisilviyan sendrom; düşme atağl; epilepsy; polimikrogri.

\section{Introduction}

Congenital bilateral perisylvian syndrome (CBPS) is a congenital neuronal migration disorder characterized by epilepsy, pseudobulbar palsy, cognitive deficits and bilateral perisylvian abnormalities at brain imaging. ${ }^{[1]}$
Epileptic seizures are present in the majority of cases with CBPS, with a broad spectrum of seizure types, including generalized tonic-clonic (GTC), typical and atypical absences, atonic and tonic seizures or drop attacks. ${ }^{[1,2]}$ 
We report a case of a 44-year-old male with a history of seizures from the age of 13 years, presenting with drop attacks and diagnosed with CBPS after detailed history, neurological examination and magnetic resonance imaging (MRI) findings.

\section{Case Report}

A 44-year-old left-handed male was admitted to our hospital due to epilepsy and recurrent episodes of drop attacks. The patient was delivered vaginally on term after an unremarkable pregnancy. He had no history of perinatal disease, febrile seizures, head trauma or central nervous system infections. He had four brothers with no health problems. No family history of seizures, epilepsy or progressive neurological disorder was reported.

The patient had an orthopedic abnormality in his right foot from birth. He was unable to walk alone until undergoing surgery to the right foot at the age of 7 . Following that operation he started walking alone, albeit with difficulty. Otherwise he had normal developmental milestones and graduated from primary school (5 years).

He started having seizures at the age of 13. These were described as GTC seizures, at a frequency of one or two per week. He was given diazepam $5 \mathrm{mg}$ orally daily but continued having seizures once per week. However, he was not ad- mitted to any other hospital and continued using diazepam for 15 years. After that time, in addition to continuing weekly GTC, he also started having sudden falls. Drop attacks occurred while sitting or standing. He was admitted to a neurologist for the drop attacks, and medication was changed to carbamazepine $800 \mathrm{mg}$ daily. Following initiation of carbamazepine, frequency of GTC seizures decreased to once a month, but he continued having 2 or 3 drop attacks per month. The carbamazepine dosage was increased to 1200 mg daily after 3 years due to the gradually increasing frequency of seizures. The patient used carbamazepine for 9 years without any medical supervision. He continued having GTC seizures once per week. The frequency of drop attacks gradually increased to 2 or 3 per week, and sometimes to once or twice a day. Levetiracetam $3000 \mathrm{mg}$ daily was added to treatment by a neurologist, after which GTC occurred once a month, but drop attacks continued at the same frequency.

The patient was first admitted to our clinic due to recurrent episodes of drop attacks in November 2013. He was able to walk alone, but with difficulty. He had dysarthria, nasal speech, dysphagia and drooling, which relatives said had begun after the onset of seizures. Neurological examination revealed mild spastic quadriparesis with right-sided predominance (Modified Ashworth Scale grade 1). Gag reflex could be elicited. Deep tendon reflexes were hyperactive, and plantar reflexes were bilateral flexor. Brief cognitive assessment test demonstrated short-term memory impair-

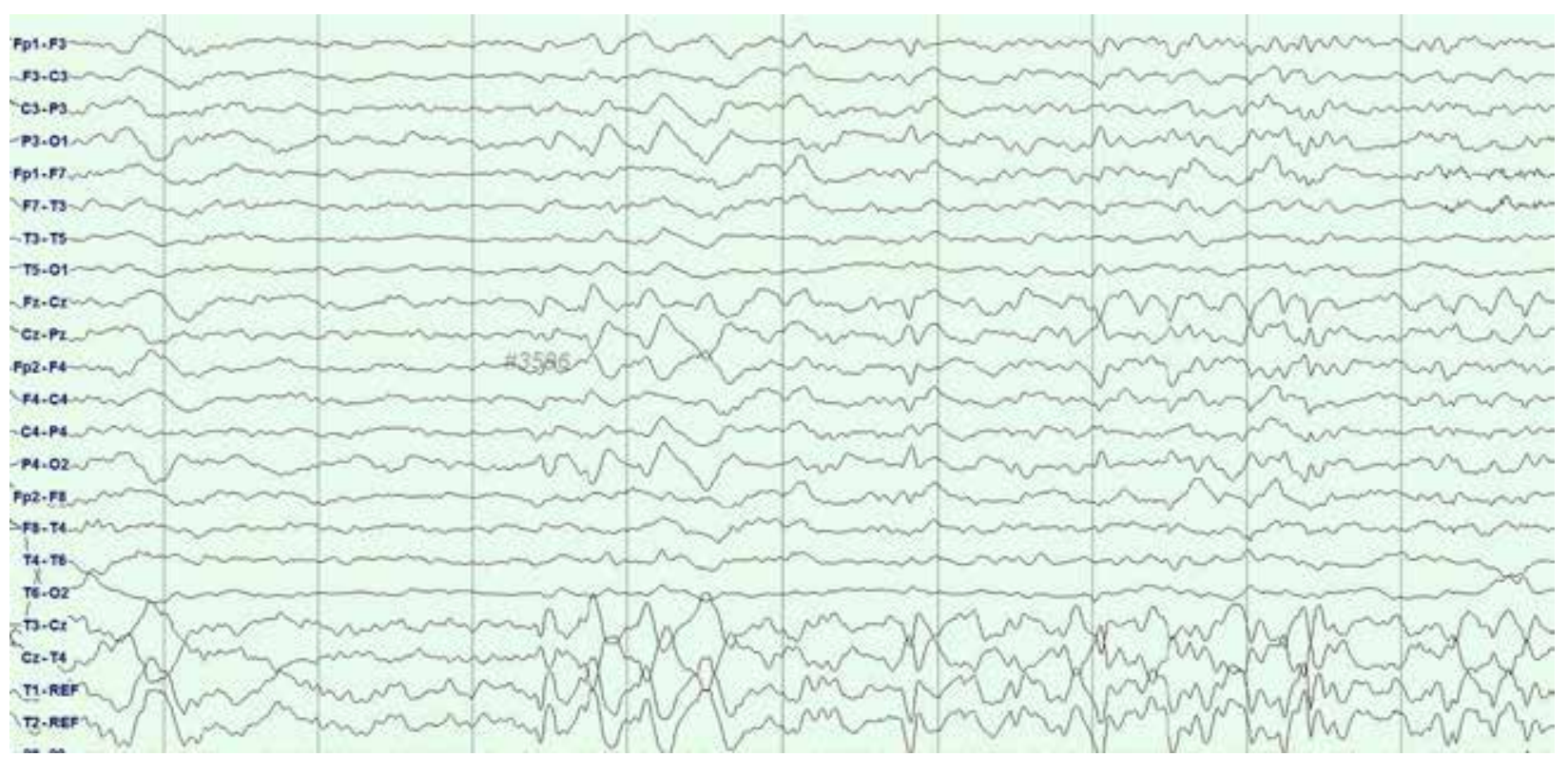

Fig. 1. Interictal sleep electroencephalogram (EEG) demonstrating bilateral centro-parietal sharp and slow wave discharges. 
ment; his intelligence quotient (IQ) was 90.

Routine laboratory blood and urine tests were normal. Interictal electroencephalogram (EEG) revealed bilateral frontotemporal sharp-slow wave discharges (Figure 1). During video EEG monitoring he had 8 drop attacks while sitting or walking. Drop attacks were characterized by a sudden head drop and forward flexion of the upper body. Ictal EEG revealed generalized frontally predominant rhythmic fast activity.

Cranial computed tomography revealed bilateral focal cor- tical thickening extending to the level of the vertex along the sylvian fissure (Figure $2 a, b$ ). MRI revealed thickening of the perisylvian cortex continuous with the central sulcus and bilateral irregularity of the cortical-white matter junction around the sylvian fissure, suggesting polymicrogyria, which is typical for CBPS (Figure 2c, d).

Diagnosis of CBPS was made on the basis of the typical clinical and neuroimaging findings. Valproic acid treatment was substituted for carbamazepine. After 1 month there was no change in seizure frequency, and the dosage of valproic acid was increased. The patient is still on follow-up
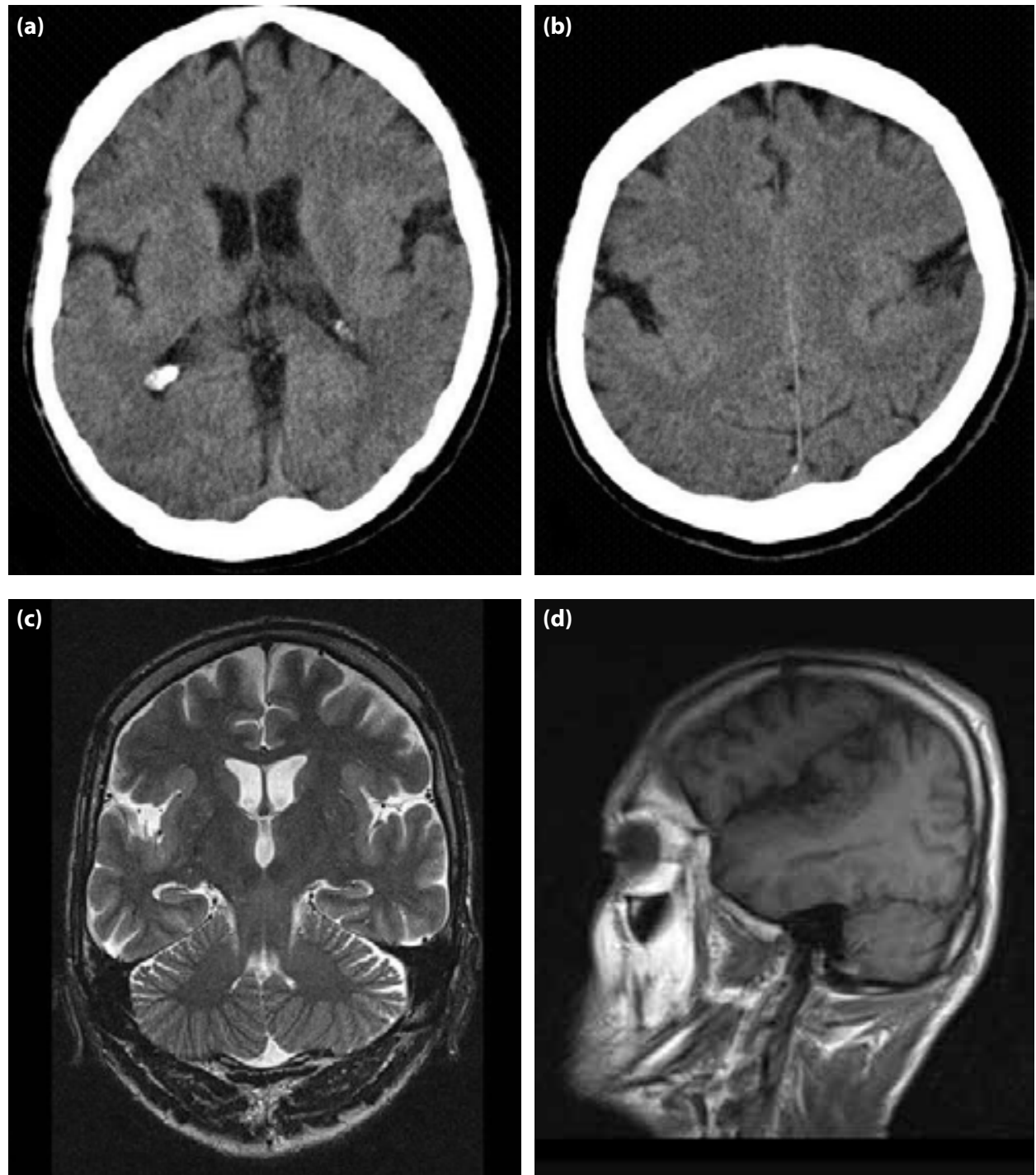

Fig. 2. (a, b) Cranial computed tomography demonstrating bilateral focal cortical thickening extending to the level of the vertex along the sylvian fissure. Brain MRI scan demonstrating perisylvian polymicrogyria in (c) coronal and (d) sagittal views. 
under combined daily therapy of levetiracetam $3000 \mathrm{mg}$ and valproic acid $2000 \mathrm{mg}$.

\section{Discussion}

We describe an epileptic patient with poor seizure control with no regular neurological follow-up. Although our patient exhibited typical clinical and neuroradiological features associated with CBPS, diagnosis was delayed due to lack of detailed assessment.

CBPS is a migration disorder characterized by bilateral perisylvian polymicrogyria which can lead to serious neurological disability due to intractable seizures, pseudobulbar paresis resulting in dysarthria and swallowing difficulties and cognitive deficits. Our patient also had mild spastic quadriparesis with right-sided predominance and dysarthria, nasal speech, dysphagia and drooling. The postulated mechanisms include cerebral hypoxia/ischemia, injury during neuronal migration and gene mutation, however the exact cause of this syndrome or the timing of the development of the malformation remains unknown. ${ }^{[1-4]}$ Although the majority of cases of CBPS appear to be sporadic, reports of cases including twins and siblings suggest a genetic predisposition. However, different modes of inheritance including X-linked, autosomal dominant and autosomal recessive from different families have been reported and the mode of transmission remains unknown. ${ }^{[1,2,5-7]}$ Although it has been reported that prenatal diagnosis may be difficult due to the possibility of not reaching the final folding until birth, there are case reports of patients diagnosed with polymicrogyria by prenatal MRI and ultrasound. ${ }^{[2,8,9]}$ Recognition of the disorder enables early appropriate management of the disabilities and seizures.

Epilepsy has been reported to be present in more than $85 \%$ of cases with CBPS, with onset usually between the ages of 4 and 12. ${ }^{[1,5]}$ Kuzniecky et al. reported that the most frequent seizure types included atypical absence, atonic/ tonic seizures or drop attacks and, tonic-clonic seizures, and less frequently partial attacks. ${ }^{[1]}$ Our patient presented with GTC seizures at the age of 13 and drop attacks at the age of 28. Although seizures in CBPS are usually resistant to antiepileptic medications in most cases, there are also reports of seizures being well controlled with pharmacological therapy or surgery. Frequency of GTC seizures in our patient decreased to once a month with levetiracetam, but tonic/atonic drop attacks persisted at the same frequency as before. Corpus callosotomy has been reported to be a useful treatment in patients with disabling seizures, especially with intractable drop attacks. ${ }^{[1,2,5]}$ Kuzniecky et al. reported pronounced seizure reduction, improved behavior and social adaptation after surgery in their patients. ${ }^{[1]}$ This may also be an option in our patient after regular follow-up, readjustment of antiepileptic therapy and evaluation of the clinical response.

Kuzniecky et al. described the clinical and laboratory features of 31 patients with CBPS. EEG demonstrated generalized or bilateral spike and wave discharges in 50\% of these. [1,4] Perisylvian abnormalities at imaging and motor symptoms tend to be symmetrical in most cases. However, relatively asymmetric involvement of one side has also been reported. ${ }^{[1,4,5,10]}$ Our patient also exhibited right-sided predominance in motor symptoms, but symmetric abnormalities at neuroimaging.

Although mental retardation is regarded as one of the characteristic features of this syndrome ${ }^{[1]}$ Donders et al. reported that individuals with CBPS may present with heterogeneous psychological presentation and that cognitive impairment may not be as prevalent as previously suggested ${ }^{[5]}$ Our patient also had mild cognitive impairment, which supported Donders' observation. Kuzniecky et al. also reported varying degrees of mental retardation, from mild to severe, in their case series. ${ }^{[1]}$ However, only the BCAT and IQ test were used in our case, and revealed average IQ and mild short-term memory impairment. More comprehensive neuropsychological evaluation might have been more informative. The location of the polymicrogyria also has an important effect on symptom complexes and prognosis. Barkovich et al. reported that patients with bilateral frontal polymicrogyria had more severe motor delay than speech delay, mild mental retardation and lower frequency of seizures, whereas patients with perisylvian polymicrogyria presented more frequently with speech dysfunction. ${ }^{[6]}$

CBPS has been reported to be associated with malformations such as arthrogryposis, ${ }^{[1]}$ clubfeet, $^{[1]}$ micrognathia, ${ }^{[1]}$ polydactyly, constriction band syndrome ${ }^{[3]}$ and pituitary abnormalities. ${ }^{[11,12]}$ Thirteen to thirty-three percent of cases have been reported to be associated with arthrogryposis multiplex congenital, which is characterized by joint contractures from birth. ${ }^{[13]}$ Our patient also had an orthopedic abnormality in his right foot at birth which was thought to 
be clubfoot, and underwent surgery when he was 7 . He had no other joint abnormalities suggestive of arthrogryposis multiplex congenita. Association of skeletal abnormalities suggests that genetic factors may be involved. ${ }^{[13]}$

This case report emphasizes the importance of detailed investigation in patients with epilepsy, especially patients with refractory seizures for the possibility of identifying a specific syndrome. Intractable seizures, pseudobulbar signs and mental retardation suggest the diagnosis of CBPS. MRI of the brain plays an important role in the diagnosis of this syndrome.

\section{References}

1. Kuzniecky R, Andermann F, Guerrini R. Congenital bilateral perisylvian syndrome: study of 31 patients. The CBPS Multicenter Collaborative Study. Lancet 1993;341(8845):608-12.

2. Gowda AK, Mane RS, Kumar A. Congenital bilateral perislyvian syndrome: case report and review of literature. J Clin Neonatol 2013;2(4):196-8.

3. Yamanouchi H, Ota T, Imataka G, Hagiwara Y, Nakagawa E, Eguchi M. Congenital bilateral perisylvian syndrome associated with congenital constriction band syndrome. J Child Neurol 2002;17(6):448-50.

4. Kuzniecky R, Andermann F. The congenital bilateral perisylvian syndrome: imaging findings in a multicenter study. CBPS Study Group. AJNR Am J Neuroradiol 1994;15(1):139-44.

5. Donders J, Mullarkey SK, Allchin J. Congenital bilateral perisyl- vian syndrome: a case study. Clin Neuropsychol 2009;23(2):27685.

6. Barkovich AJ, Hevner R, Guerrini R. Syndromes of bilateral symmetrical polymicrogyria. AJNR Am J Neuroradiol 1999;20(10):1814-21.

7. Taneja S, Chaturvedi AK. Bilateral perisylvian syndrome - a case report. Ind J Radiol Imag 2006:16(2):169-71.

8. Righini A, Zirpoli S, Mrakic F, Parazzini C, Pogliani L, Triulzi F. Early prenatal MR imaging diagnosis of polymicrogyria. AJNR Am J Neuroradiol 2004;25(2):343-6.

9. Dhombres F, Nahama-Allouche C, Gelot A, Jouannic JM, de Villemeur TB, Saint-Frison MH, et al. Prenatal ultrasonographic diagnosis of polymicrogyria. Ultrasound Obstet Gynecol 2008;32(7):951-4.

10. Sejima H, Takusa Y, Kimura M, Tamaoki Y, Kishi K, Yamaguchi S. A variant case of congenital bilateral perisylvian syndrome with asymmetric findings on neuroimaging and septum pellucidum defect. Brain Dev 2001;23(2):131-4.

11. Toldo I, Calderone M, Sartori S, Mardari R, Gatta M, Boniver C, et al. Bilateral perisylvian polymicrogyria with cerebellar dysplasia and ectopic neurohypophysis. J Child Neurol 2011;26(3):361-5.

12. Yekeler E, Ozmen M, Genchellac H, Dursun M, Acunas G. Congenital bilateral perisylvian syndrome with pituitary hypoplasia and ectopic neurohypophysis. Pediatr Radiol 2004;34(11):90811.

13. Poduri A, Chitsazzadeh V, D’Arrigo S, Fedrizzi E, Pantaleoni C, Riva $D$, et al. The syndrome of perisylvian polymicrogyria with congenital arthrogryposis. Brain Dev 2010;32(7):550-5. 